\title{
Research Paper: The Effectiveness of Group Social Work Intervention With Develop- mental Approach on Psychosocial Empowerment of Female-Headed Households
}

\author{
"Elham Torabi Momen¹, Ghoncheh Rahebㄹ, Fardin Ali Pour ${ }^{1}$, Akbar Biglarian² \\ 1. Department of Social Work, University of Social Welfare and Rehabilitation Sciences, Tehran, Iran. \\ 2. Department of Biostatistics, Pediatric Neurorehabilitation Research Center, University of Social Welfare and Rehabilitation Sciences, Tehran, Iran.
}

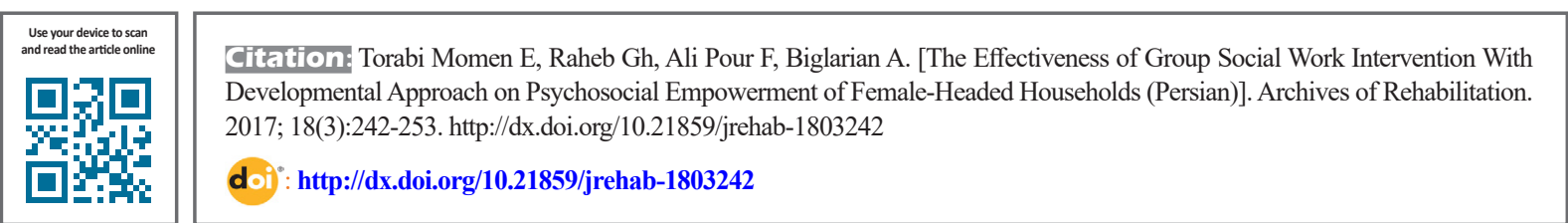

Received: 1 Apr. 2017

Accepted: 15 Jul. 2017
Keywords:

Social work with

group, Psychosocial

empowerment

Female headed

households

\section{A B STRACT}

Objective Female-headed households are one of the minority groups of women in Iran and other countries, grappling with many problems. This group normally face with too many obstacles in their personal, family and social life. So much difficult tasks assigned to these women, put unbearable pressure and tensions on them, and gradually makes them susceptible to a variety of mental disorders. Considering the wide range of issues, problems, limitations and vulnerability of female-headed households and their being as one of the target groups of social workers; it is important to provide professional services by social workers with the aim of psychosocial empowerment of this group. Thus the present study aimed to investigate the effectiveness of group social work intervention with developmental approach on psychosocial empowerment of female-headed households. Materials \& Methods This research was quasi-experimental with pretest/posttest design and control group. The study population consisted all female-headed households living in Tehran. The sample of women heads of households were randomly chosen from the Guide Institute of Imam Ali (AS). The inclusion criteria were the ability to read and write, aged 20 to 45 years, and willingness to participate in the study. Finally, a total of 60 women heads of households were selected and randomly divided into two intervention and control groups. Group social work intervention with developmental approach was taught in eight 90-minute sessions to the experimental group. The control group did not receive intervention. In order to assess the psychosocial empowerment of women heads of household before the first session and after the last session, social demographic data and psychological empowerment questionnaire were distributed among the participants and were filled by them. In this study, questionnaires on demographic information and Moradi (2010) sociopsychological empowerment questionnaire were used. Construct validity and reliability of the questionnaires have been approved. Also the validity and reliability of the questionnaire was assessed by the investigator again. The Cronbach $\alpha$ of the questionnaire was equal to 0.79 . The content and face validity of the questionnaire were confirmed by the University of Welfare and Rehabilitation Sciences. The data were analyzed by SPSS 22 . The analyses were performed by descriptive statistics such as mean, frequency, standard deviation and inferential statistics, including Levine, KS, paired test, and covariance.

Results The results showed a significant difference between psychological empowerment of women headed households, before and after the intervention. This significant difference was observed in the scales of psychological empowerment, including self-esteem, self-efficacy, intellectual independence and sense of power $(P<0.001)$ and subscales of social empowerment, including participation in social activities and pluralism $(P<0.001)$. Also there were significant differences $(P<0.001)$ between trained and untrained people in psychological empowerment with the scales of self-esteem, self-efficacy, intellectual independence, sense of power and in social empowerment with the scales of participation in social activities and pluralism.

Conclusion According to the study results, group social work intervention sessions with psychosocial developmental approach to empowering female-headed households is effective. The wider use of this type of intervention by professionals can empower and improve the lives of this group of people.

\section{* Corresponding Author:}

Elham Torabi Momen, MA Student

Address: Department of Social Work, University of Social Welfare and Rehabilitation Sciences, Tehran, Iran.

Tel: +98 (933) 1527388

E-Mail: torabi.em@gmail.com 


\title{
بررسى اثربخشى مداخله مددكارى اجتماعى تروهى با رويكرد توسعه بر توانمندسازى روانى و اجتماعى زنان سريرست خانوار
}

\author{
"الهام ترابى مؤمن'، غنجه راهب'، فردين علىيور '، اكبر بيكلريان'

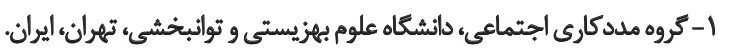

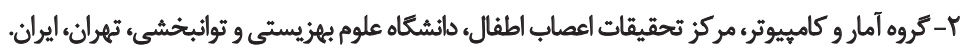

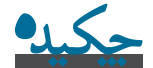

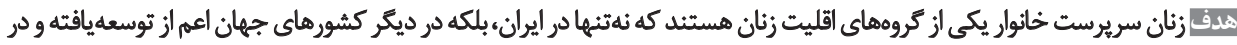

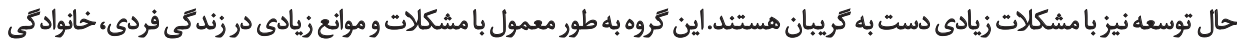

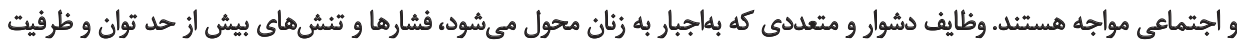

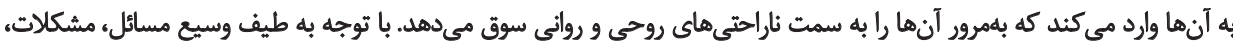

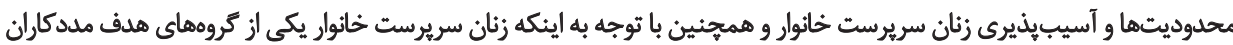

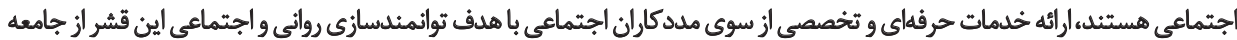

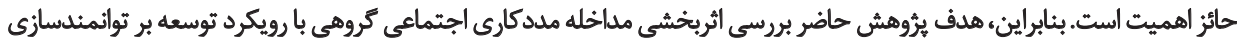

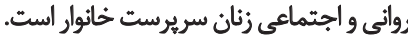

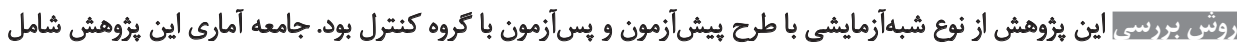

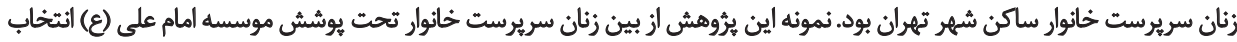

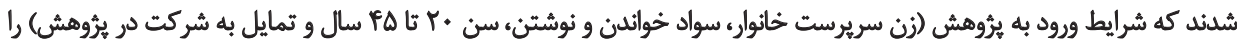

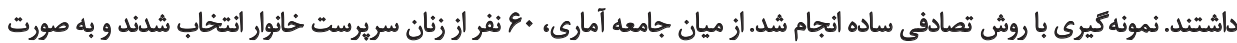

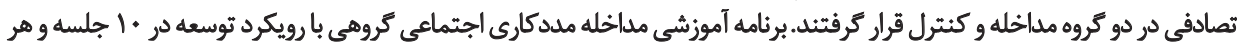

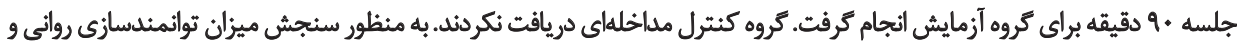

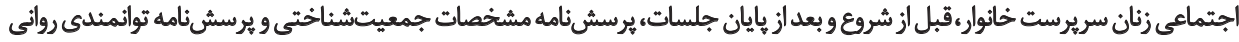

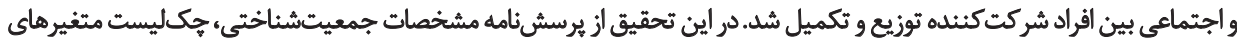

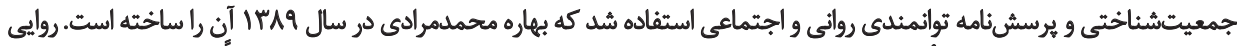

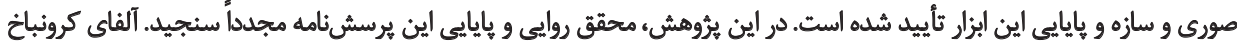

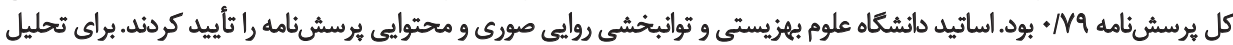

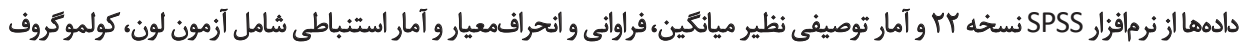

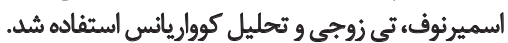

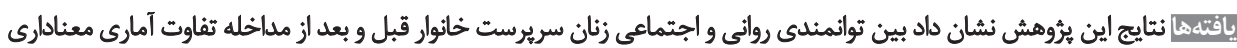

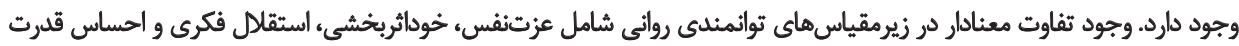

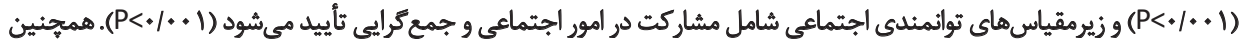

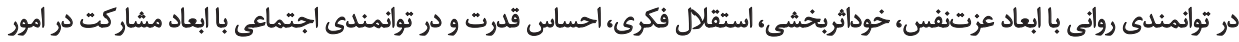

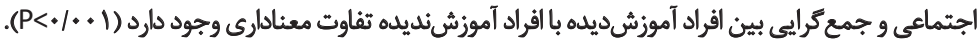

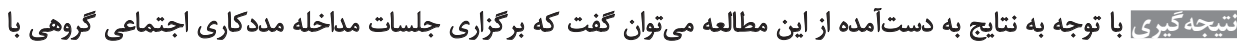

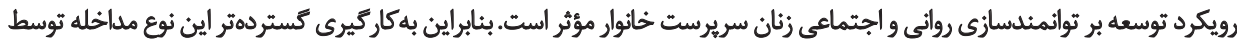

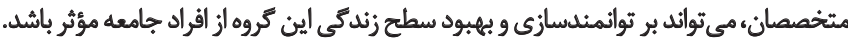

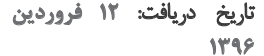

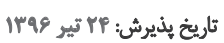

: Loglguts

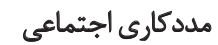
كروهي، توانمينديسازي اجتمي رواني و اجتماعي، زنان توانميان سريرست خانوار 


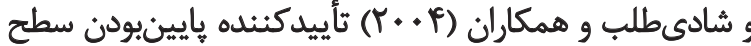

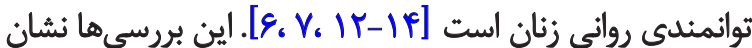

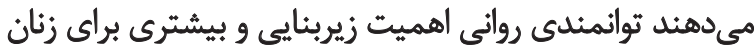

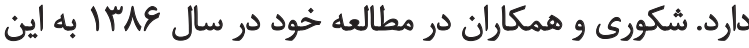

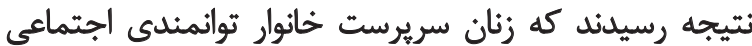

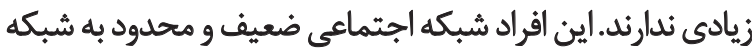

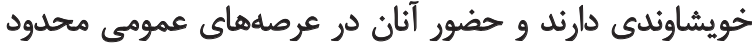

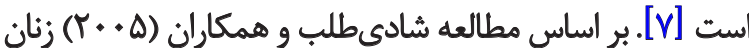

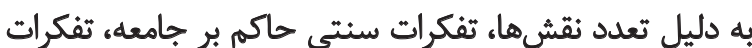

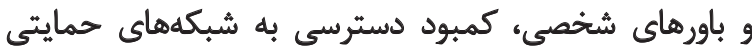

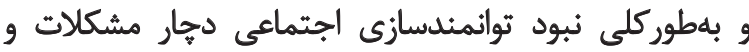

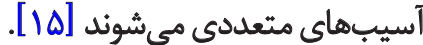

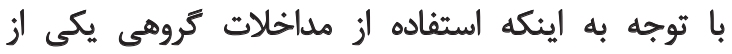

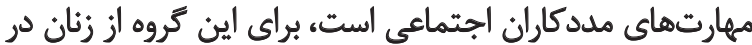

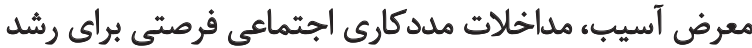

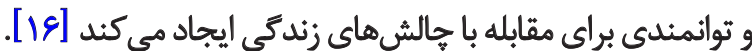

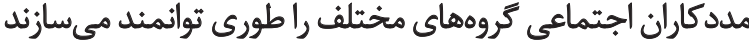

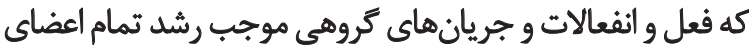

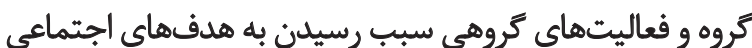

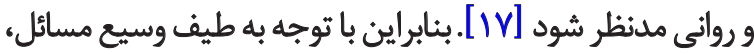

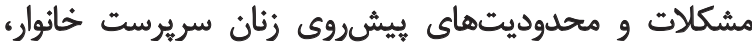

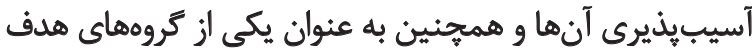

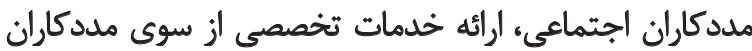

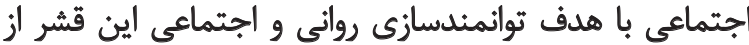

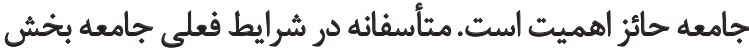

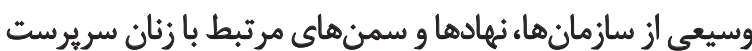

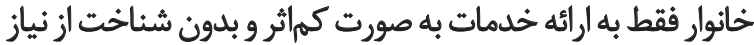

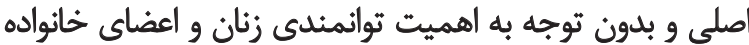

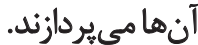

اين روند سبب بلوجودآمدن سيكل معيوبى مىشود كه

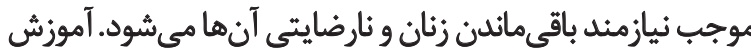

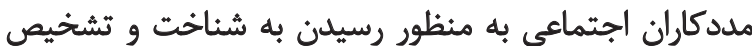

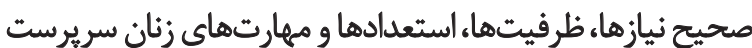

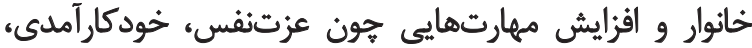

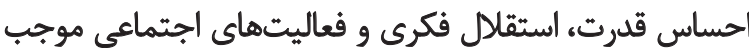

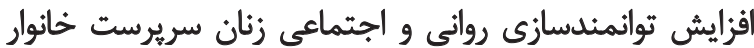

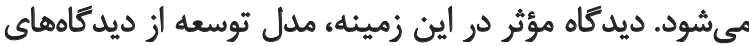

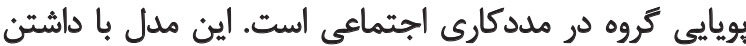

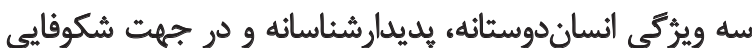

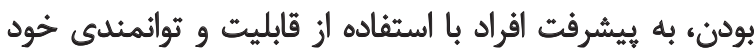

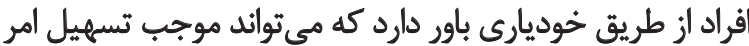
توانمندسازى روانى و اجتماعى زنان شود. ازجمله مطالعات مرتبط با موضوع مىتوان به اين مطالعات
مقدمه

زنان سريرست خانوار يكى از كروههاى اقليت زنان هستئد كه

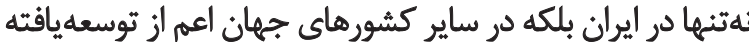

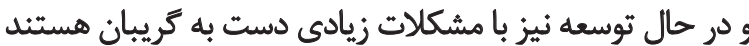

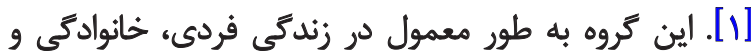
اجتماعى خويش با مشكلات و موائع زيادى مواجهيند. وظايف

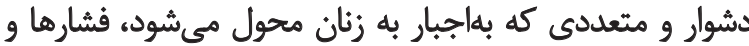

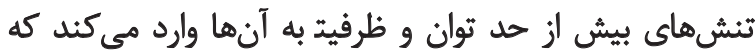

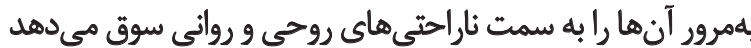

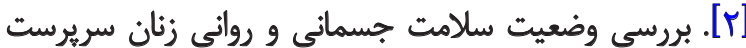

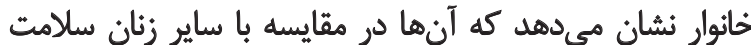

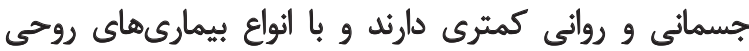

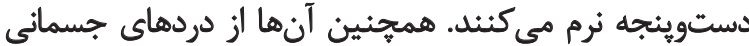

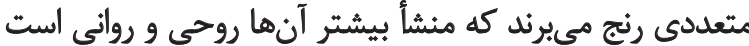

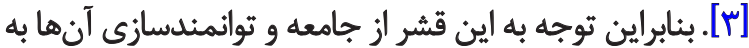
عنوان يك ضرورت مطرح مىشود.

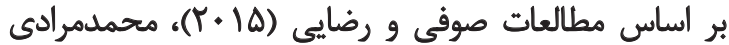

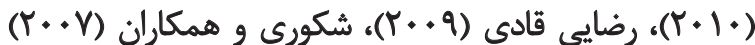

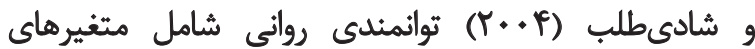

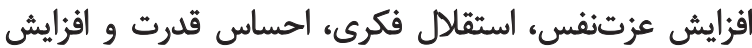

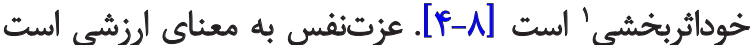

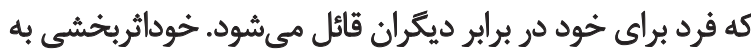

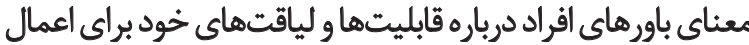

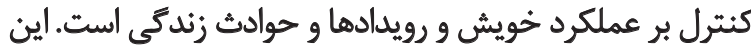

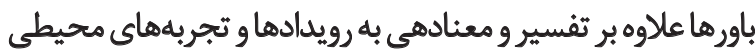

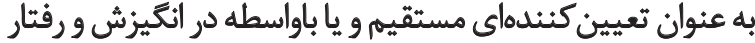

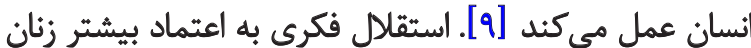

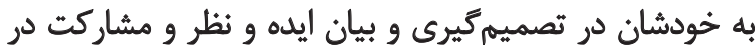

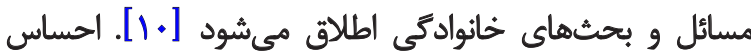

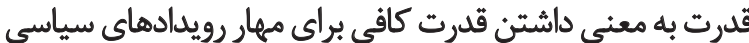

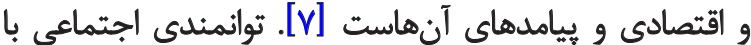

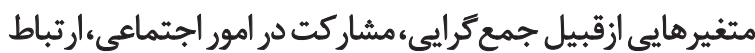

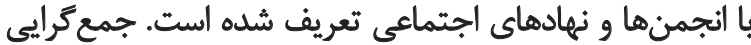

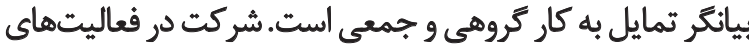

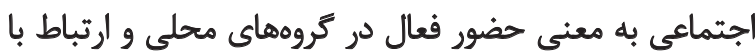
انجمنها ونهادهاى اجتماعى است [هاع] در بحث توانمندسازى زنان بهندرت به موانع روائى يرداخته

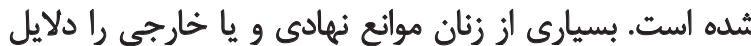

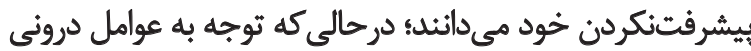

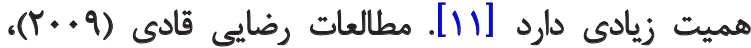

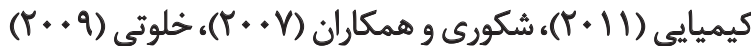


كه از خدمات اجتماعي متداول و مرسوم استفاده كردند) بود.

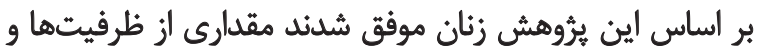

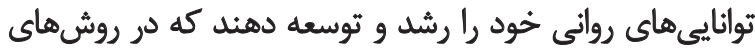

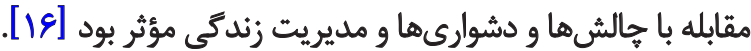

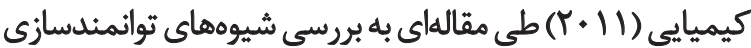

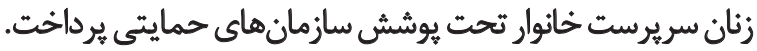

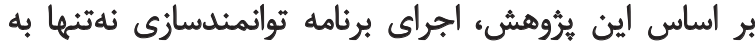

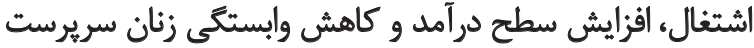

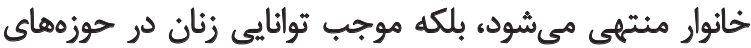

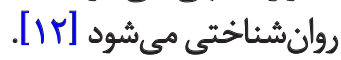

يُورهشهاى انجامشده حاكى از آن است كه زنان سريرست

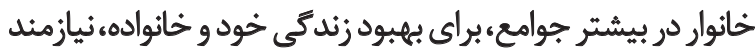

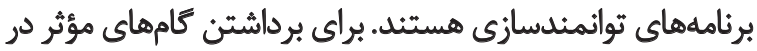

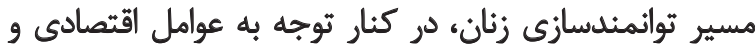

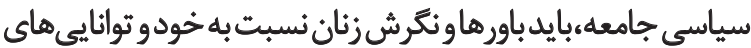

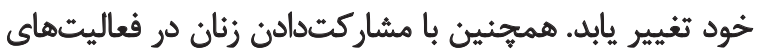

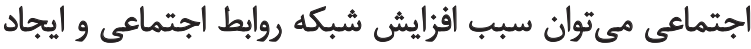

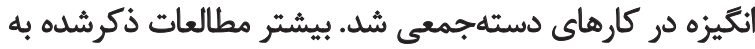

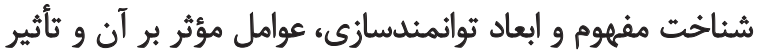

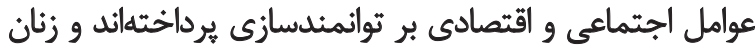

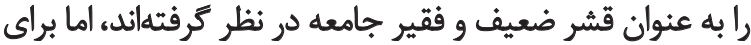

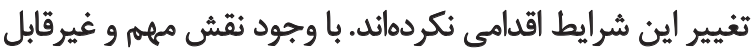

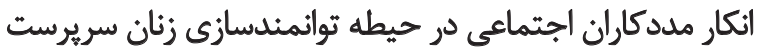

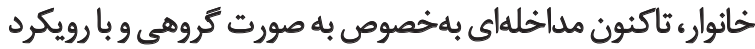

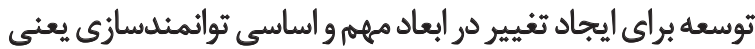

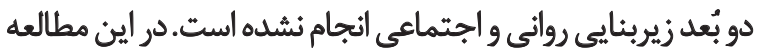

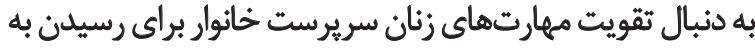

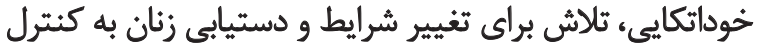

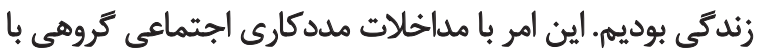

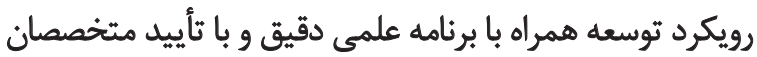
صورت يذّيرفت

هدف كلى اين مطالعه شناخت تأثير مداخله مددكارى اجتماعى

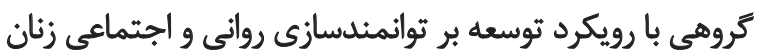

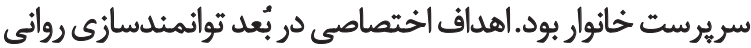

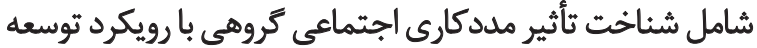

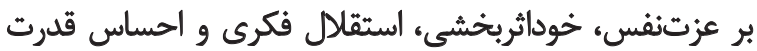

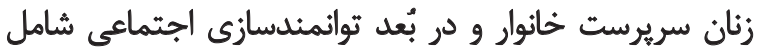

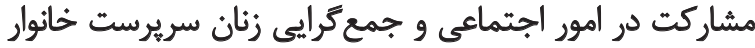

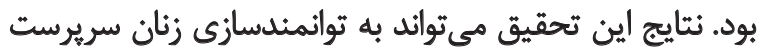

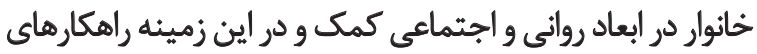

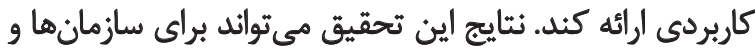

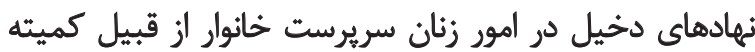

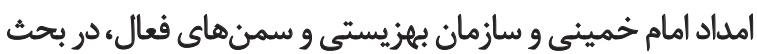
آموزش و سياست كذارى سودمند واقع شود.

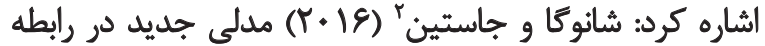

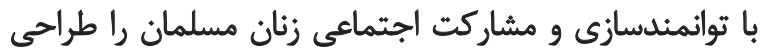

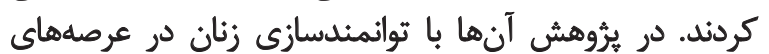

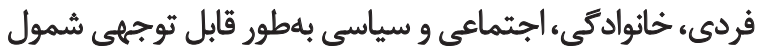

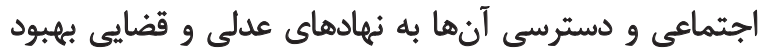

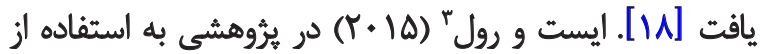

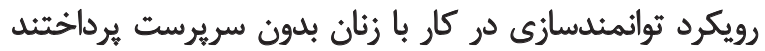

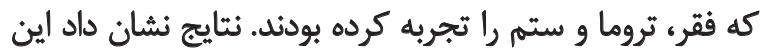

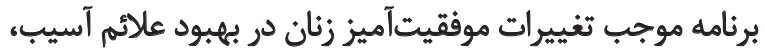

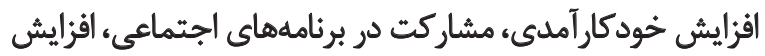

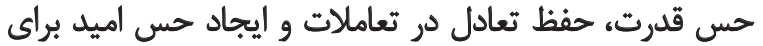

آينده شده است [19] - [19.

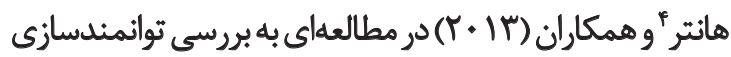

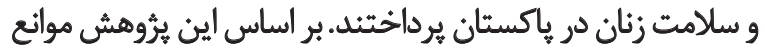

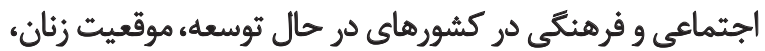

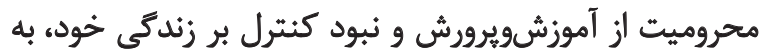

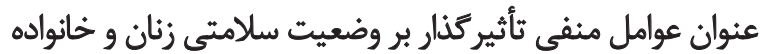

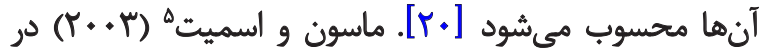

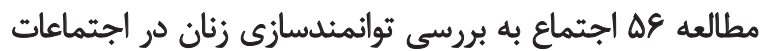

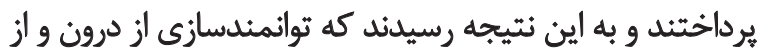

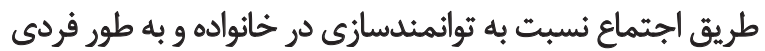

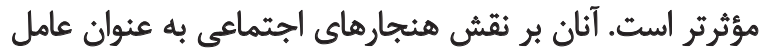

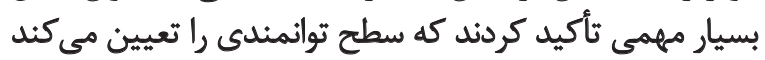

.[r.]

در مطالعات داخلى صوفى و رضايى (Y) (Y) در برؤوهشى

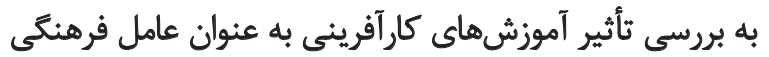

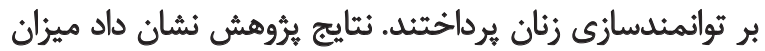

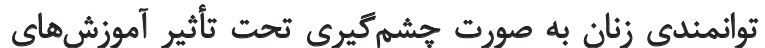

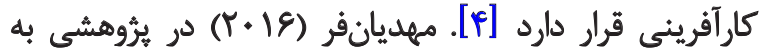

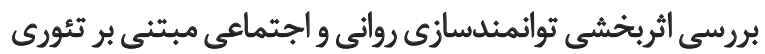

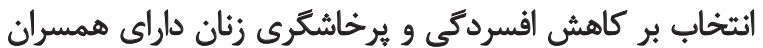

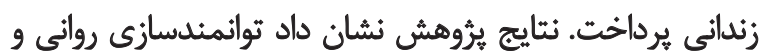

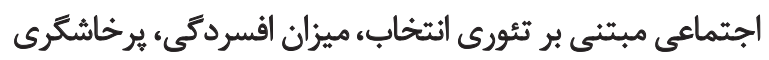

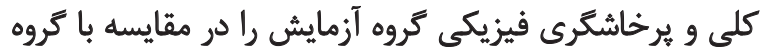

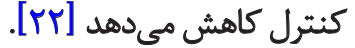

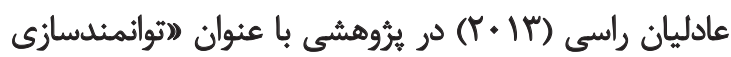

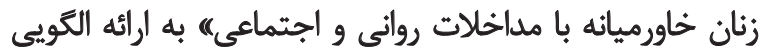

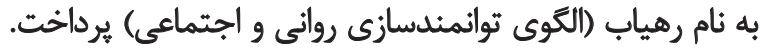

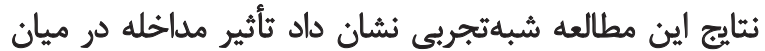

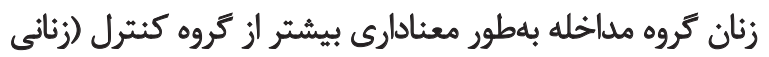

\footnotetext{
2. Shanuga and Justin

3. East and Roll

4. Hunter
}

5. Mason and Smith 
تعيين مدرسه و رسيدگى به مسائل تحصيلى فرزندان، آموختن

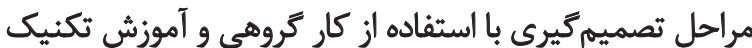

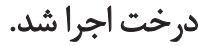

جلسه هفتم با موضوع احساس قدرت در زنان با هدف باور

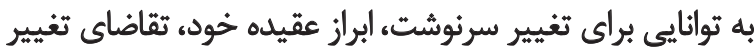

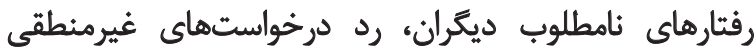

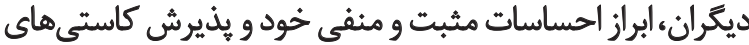

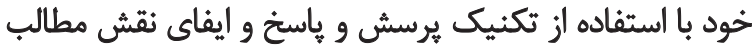

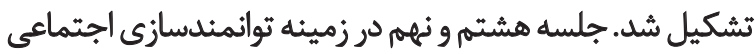

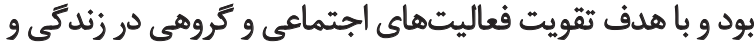

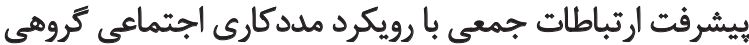

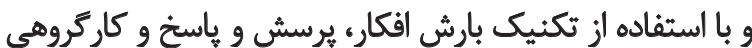

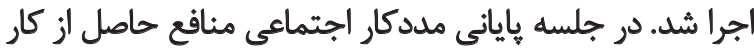

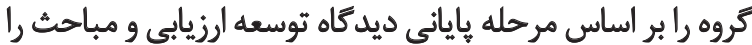

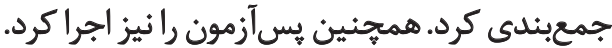

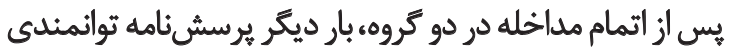

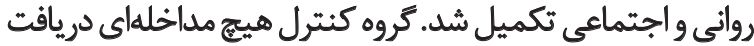

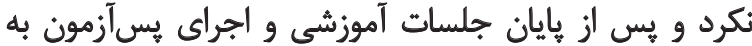

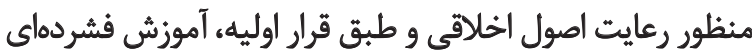

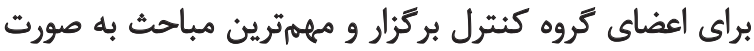

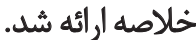

از آنجايى كه مداخله طراحىشده براي اولين بار در ايران

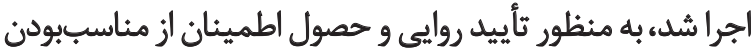

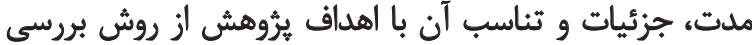

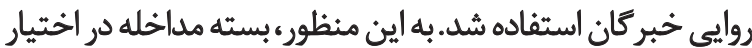

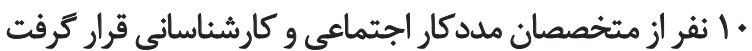

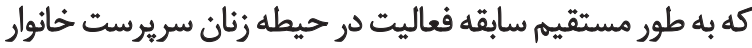

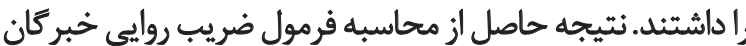

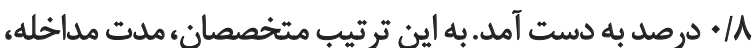
جزئيات و تناسب بسته مداخله را با اهداف برثوهش تأييد كردند.

در اين يروهش، براي سنجش ميزان توايمندى روانى و

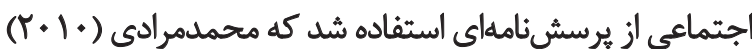

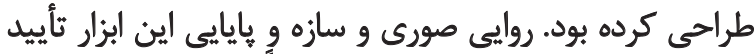

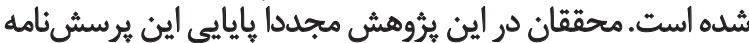

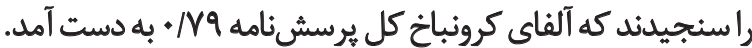

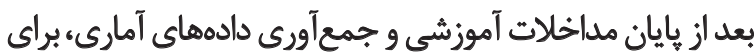

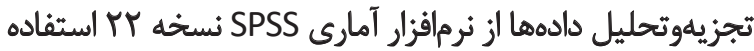

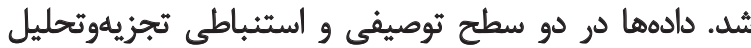

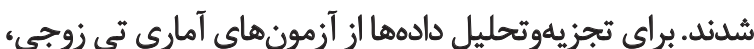
لون و تحليل كواريانس استفاده شد.

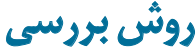

اين يُروهش از نوع شبهآزمايشى بود كه با استفاده از طرح

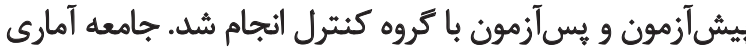

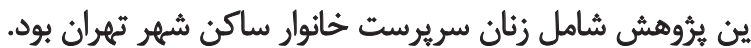

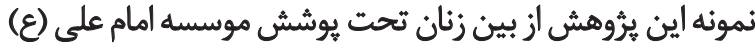

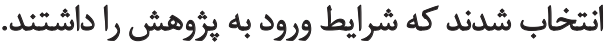

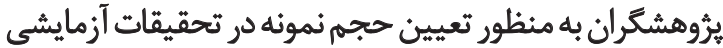

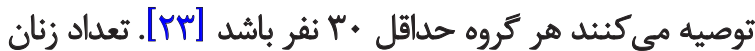

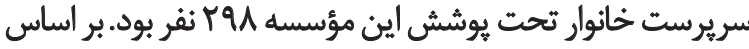

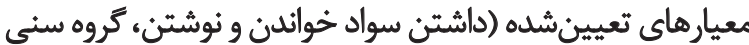

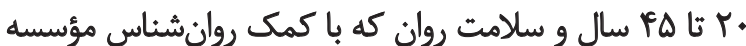

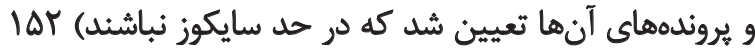

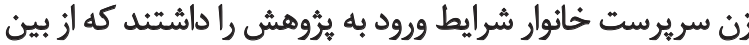

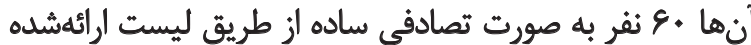

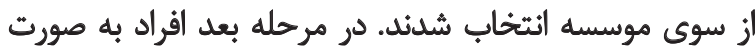

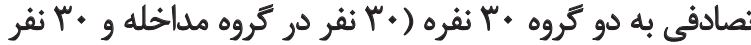

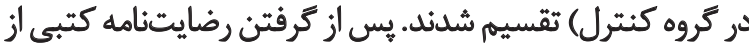

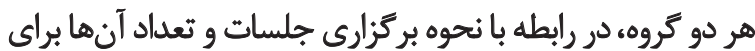

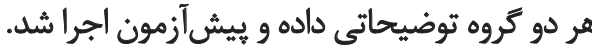

يّ از آن يُؤششكر مداخلات مددكارى اجتماعى را با رويكرد

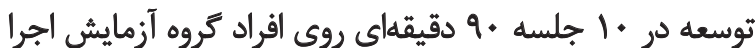

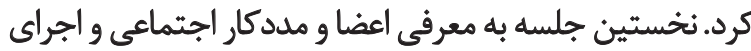

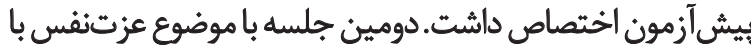

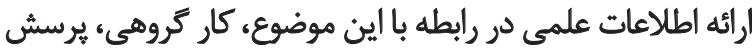

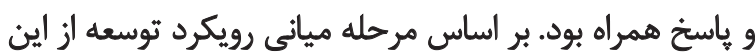

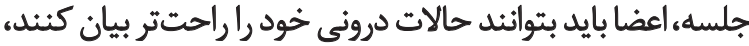

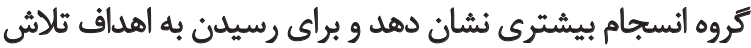

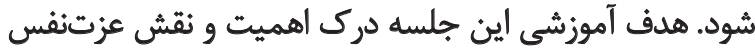

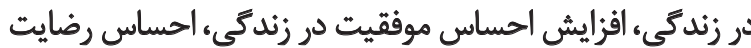

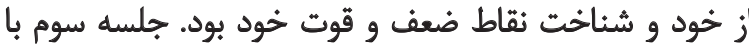

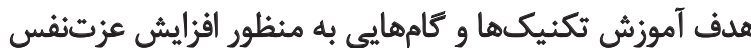

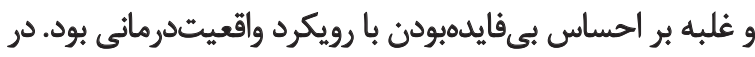

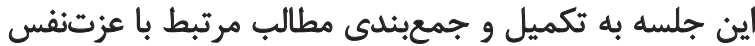

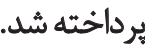

جلسه جهارم با هدف احساس توان براى بهبود وضع آينده،

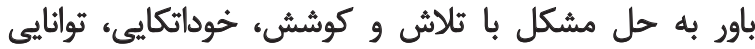

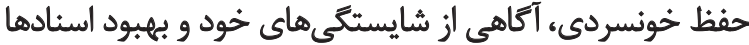

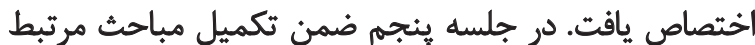

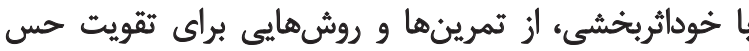

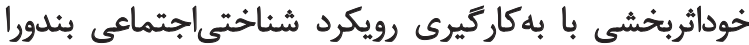

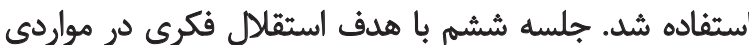

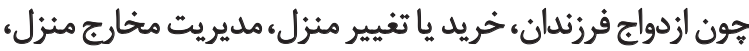


مؤلفههاي توانمندسازى روانى و اجتماعى به تفكيك گروههاى

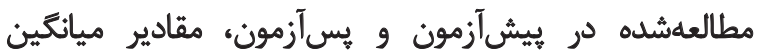

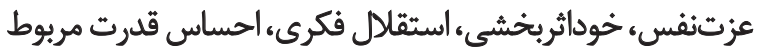

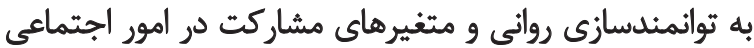

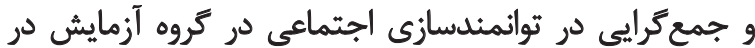

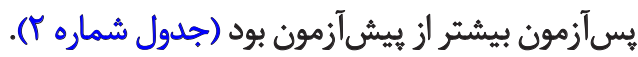
همجينين براي بررسى عادىبودن توزيع متغير هاى توانمندسازى

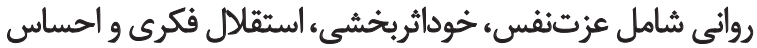

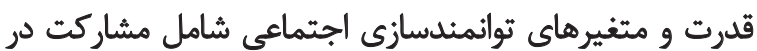

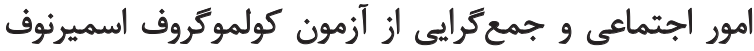

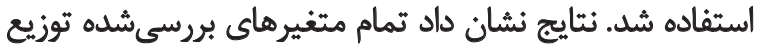

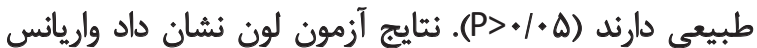

يافتهها

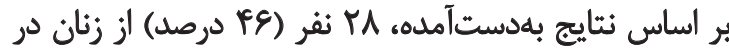

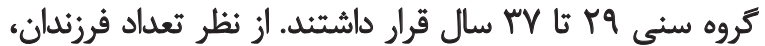

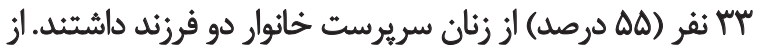

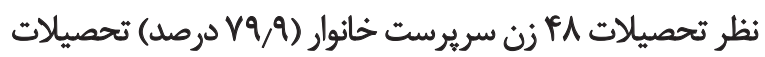

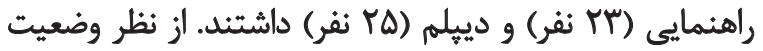

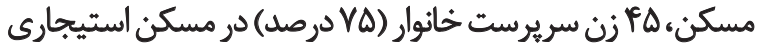

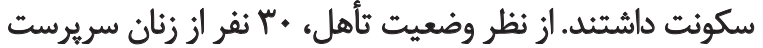

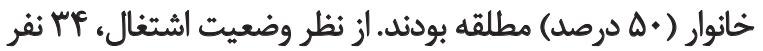

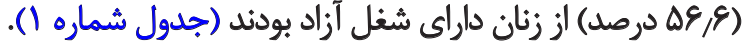
بر اساس نتايج بلدستآمده از بررسى شاخصهاى توصيفى

جدول ا. توزيع فراوانى زنان سريرست خائوار به تفكيك متغيرهاى جمعيتشناختى در كروهاي بررسى شده

\begin{tabular}{|c|c|c|c|c|}
\hline جمع - جم & كتترل & أزمايش & \multirow{2}{*}{\multicolumn{2}{|c|}{ متغيرهاى جمعيتش شُناختي }} \\
\hline تعداد (درصد) & تعداد (درصد) & تعداد (درصد) & & \\
\hline$r+(M / Y M)$ & ATE/8) & $r\left(F_{+}\right)$ & 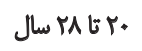 & \\
\hline$r A(F, / \epsilon)$ & $\mid f(t \& / 8)$ & $\mid F(E \& / 8)$ & 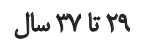 & سن \\
\hline$I r(Y \cdot / r)$ & ATEIE) & $F(1 r / T)$ & גץ تا هף سال & \\
\hline $19(T / 8)$ & $11(Y 9 / 9)$ & A(TE/E) & يك فرزثد & \\
\hline$\pi(\Delta \Delta / \cdot)$ & $1 \theta(\Delta \cdot / \cdot)$ & $W(E \circ / *)$ & دو فرزند & \\
\hline$V(11 / 9)$ & $f(I r / T)$ & $r(1 . \%)$ & سه فرزند & und \\
\hline $1(1 / 8)$ & $+(\% / \%)$ & $1(\% / r)$ & جهار فرزند & \\
\hline$M(W N)$ & $q(r+1 \cdot)$ & $\Delta(18 / 9)$ & ابتدايعى & \\
\hline$\Pi\left(\Psi_{N} M^{\mu}\right)$ & $\mid r(r+1 *)$ & $\|(r E / g)$ & راهنمايى & Elhari \\
\hline$r \Delta(P V / P)$ & $r F(p+1 \%)$ & $\mid T(9+/ T)$ & دييله & \\
\hline $1(1 / 8)$ &.$(\% / \%)$ & $1(r / T)$ & ليسأس & \\
\hline$P A(\mathrm{VA} / \cdot)$ & $\pi(A-/ \%)$ & $M(N \cdot / \cdot)$ & استيجارى & \\
\hline $\mid r(r \mid / V)$ & $9(r+1)$. & $V(T r / F)$ & مالى & وضعيت مسكن \\
\hline$r(\Psi / T)$ & $\%(\%)$ & $r(8 / 9)$ & بلدرى & \\
\hline $19(r / 8)$ & N(TS/8) & $11(Y / 9)$ & مثأهل & \\
\hline$r+(\Delta * / *)$ & $V\left(\Delta, / F^{2}\right)$ & $\mid f(E \& / 8)$ & مطلقه & وضعيت تأهل \\
\hline$\|\left(W N^{*}\right)$ & $q(r+1 \cdot)$ & $\Delta(18 / A)$ & هتوفى & \\
\hline $\operatorname{Mr}(\Delta F / F)$ & $w(8+1 \cdot)$ & $\mid q(\Delta r / T)$ & آزإد & \\
\hline$r(T / N)$ & $r(\& / A)$ &.$(\%)$ & كارمثلد & وضعيت اشتغال \\
\hline$\pi(t * 1)$. & $1 .\left(\pi / / x^{2}\right)$ & $\mid f(E \& / 8)$ & خانهدار & \\
\hline
\end{tabular}

توانبخننى 


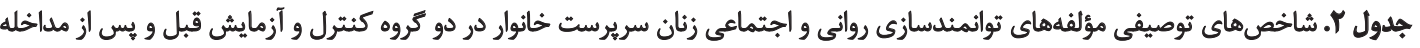

\begin{tabular}{|c|c|c|c|c|}
\hline انحرأفمعيار & مياكين & هراحل & L & مؤلفهاى توائمندسازي \\
\hline$r / q$. & IT/Ye & ييش آزّمون & \multirow{2}{*}{ كتترل } & \multirow{4}{*}{ عزثتفس } \\
\hline F/M & 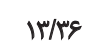 & يس آزمون & & \\
\hline r & IF/TI & ييش آزمون & \multirow{2}{*}{ آزآمايش } & \\
\hline$T / T Y$ & $r+/ N E$ & يسأزمون & & \\
\hline$r / I Y$ & Ir/Fe & ييش آزمون & \multirow{2}{*}{ كنترل } & \multirow{4}{*}{ مُوداثربِيُشى } \\
\hline$r / 19$ & $\mid w / \%$ & يس آزمون & & \\
\hline$r / \wedge q$ & IV/aT & يبيش آزآمون & \multirow{2}{*}{ أزمايش } & \\
\hline $1 / 91$ & $W n$ & هָسآزمون & & \\
\hline F/Ar & $19 / \%$ & ييش أَزمون & \multirow{2}{*}{ كنترل } & \multirow{4}{*}{ استقلال فكرى } \\
\hline$e / q \Delta$ & $\mid Q / V$ & يسآزمون & & \\
\hline$r / 19$ & IV/ar & ييش آلزمون & \multirow{2}{*}{ 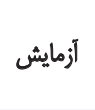 } & \\
\hline$\left.|/|\right|_{1}$ & $W N^{w}$ & يس آزهون & & \\
\hline$r / \bullet 1$ & $N N^{N}$ & ييش آزّمون & \multirow{2}{*}{ كنترل } & \multirow{4}{*}{ الحساسب قلرث } \\
\hline$H / \bullet \Lambda$ & $N \Delta S$ & يسآزهون & & \\
\hline T/VA & V.\& & ييش أزيمون & \multirow{2}{*}{ آزمايش } & \\
\hline $\mid M$ & $\mid r / M$ & يس آزمون & & \\
\hline $11 / T$ & Dive & يبيش أزمهون & \multirow{2}{*}{ كتترل } & \multirow{4}{*}{ تواتمثلدسازى روانى } \\
\hline $11 / \pi$ & $\Delta \cdot / 9 \mu$ & يسأزهون & & \\
\hline$s / t r$ & $\Delta \Delta / \Psi F$ & ييش آزأمون & \multirow{2}{*}{ آزمايش } & \\
\hline$N M^{*}$ & $89 / 9 \pi$ & يس آزمون & & \\
\hline $9 / \pi$ & $M T / T$. & ييش أزمون & \multirow{2}{*}{ كتترل } & \multirow{4}{*}{ هشاركت در امور اجثماعى } \\
\hline$g / F i$ & M & يسآزمون & & \\
\hline $9 / 49$ & $M F / q_{.}$ & يبش أَزمون & \multirow{2}{*}{ آزمايش } & \\
\hline r/ar & $r g / v$ & يسآزمون & & \\
\hline$r / 4 \Delta$ & $\mid F / \Delta T$ & ي يش آزمون & \multirow{2}{*}{ كتترل } & \multirow{4}{*}{ جمع كرايي. } \\
\hline T/Ae & I & يسآزهون & & \\
\hline$r / f \cdot$ & $10 / 18$ & يبيش آلزمون & \multirow{2}{*}{ أزمايش } & \\
\hline$r / .9$ & $\mid Q / F e$ & بس آزمون & & \\
\hline$V / I r$ & rNNT & ييش آلزمون & \multirow{2}{*}{ كتثرل } & \multirow{4}{*}{ توائمندسازي إجتماعى } \\
\hline$V / F q$ & rNIF & يس آزمون & & \\
\hline$V / \%$. & 6.1 .9 & ييش آزآمون & \multirow{2}{*}{ آزمايش } & \\
\hline$e / 4$. & $\Delta r / \bullet$ & يس آزمون & & \\
\hline
\end{tabular}

توانبخننى

تحليل كوواريانس استفاده شد. بر اساس نتايج بهدادست آمده، بين

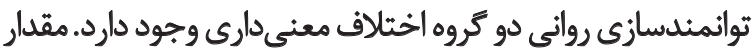

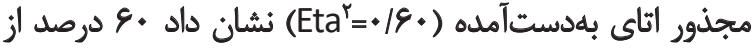
تغييرات توانمندسازى روانى آزمودنى هاى شركت كنينده در تروه

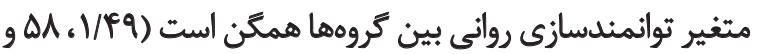

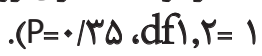

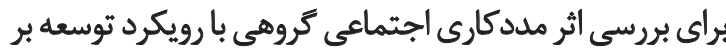

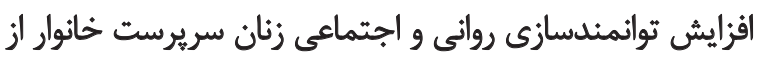


جدول "ا. تحليل كوواريانس توانمندسازى روانى و مؤلفههاى آن در كروههاى آزمايش و كنترل در زنان سريرست خانوار

\begin{tabular}{|c|c|c|c|c|c|c|}
\hline مجذور اتا & معنى سطارى & Fقدار F م F & ازوزادى & ميانكين مجذورات & مجموع مجذورات & منيع تغييرات \\
\hline .181 & $<* 1 \cdot .1$ & $\mid r e / M e$ & 1 & TrQQ/AT & TrQA/GT & ييش آذزمون توانمندسازى روانيى \\
\hline \multirow[t]{3}{*}{.18.} & $<\cdot 1 \cdot \bullet \mid$ & WAS & 1 & MI\%/9Q & MIF/qA & يين كروهـا \\
\hline & & & or & TE/ & $1 F 91 / 19$ & درون Sروهها \\
\hline & & & 8. & & rowm & كل \\
\hline.$/ F V$ & $<\bullet / . \bullet 1$ & $\Delta V / N$ & 1 & raplefe & rateler & ييش آزمون عزتنفس \\
\hline \multirow[t]{3}{*}{ r } & $<* / . \bullet 1$ & qV/aV & 1 & $\Delta E T / Q$. & $\Delta E / q$. & بين كروهها \\
\hline & & & $\Delta r$ & $\Delta / V \varepsilon$ & TrNFA & ندرون كروهها \\
\hline & & & 8. & & $|A| A F \mid$ & 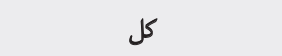 \\
\hline.$/ 48$ & $<\bullet / \bullet 1$ & 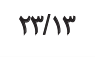 & 1 & MrV/a. & MrV/q. & ييش أزمون خودائربخشى \\
\hline \multirow[t]{3}{*}{.$/ 94$} & $<* \% \cdot$ & $1.1 / \pi$ & 1 & rq/at & PqAT & بين كروها \\
\hline & & r.ME & $\Delta v$ & $r / \mu \varphi$ & $1 \% q / \Delta q$ & دون Soون \\
\hline & & & 8 & & 1\%9ุด & كل \\
\hline.$/ 1 F$ & $<\cdot 1 \cdot \bullet 1$ & $1 \% \cdot / 9 \Delta$ & 1 & $\Delta F q / / F$ & $\Delta F q / I F$ & ييش آزرمون استقّلال فكرى \\
\hline \multirow[t]{3}{*}{.189} & $\%$ & $9 / w$ & 1 & $r=/ 99$ & $P+/ 99$ & بين كروهها \\
\hline & & & $\Delta V$ & $4 / 19$ & $n \pi q \cdot r$ & درون كروهها \\
\hline & & & 8. & & $|A Y| \mid$ & كل - مل - مل \\
\hline.$/ A F$ & $<+/ * \bullet$ & $+\varepsilon /+r$ & 1 & $\mid F I / T Y$ & $181 / T$ & ييشآزمون احساس قلرث زنان \\
\hline \multirow[t]{3}{*}{${ }^{*} / \mathrm{YA}$} & $<\bullet / . \bullet 1$ & FNE & 1 & $18+119$ & $1 \gamma+/ 1 q$ & بين كروهها \\
\hline & & & $\Delta V$ & $r / \Delta+$ & 1998. & درون كروهها \\
\hline & & & 8 & & eqra & كل \\
\hline
\end{tabular}

توانبخننى

اجتماعى دو تروه اختلاف معنى دارى وجود دارد. مقدار مجذور

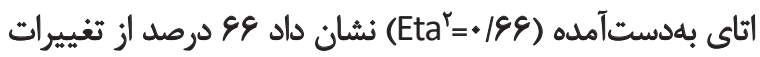

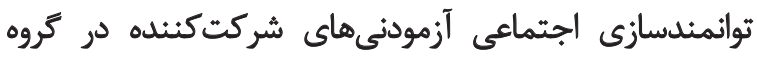

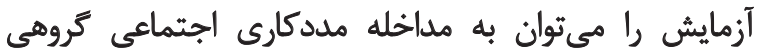

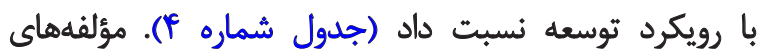

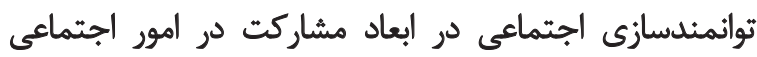

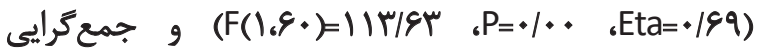

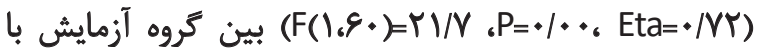

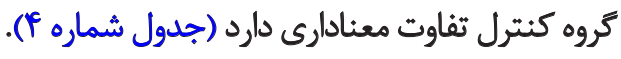
بحث

نتايج اين برؤشش نشان داد بين توانمندسازى روانى و اجتماعى و هر يك از زيرمقياس هاى آن بين افراد آموزش بديده با افراد كروهائ
آزمايش رامىتوان به مددكارىاجتماعى گروهى با رويكرد توسعه

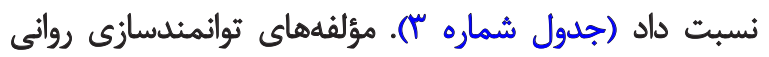

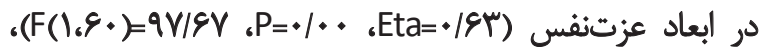

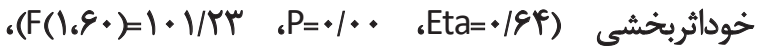

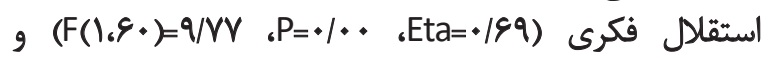

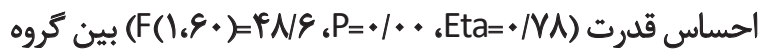
آزمايش با كروه كنترل تفاوت معنادارى دارد (جدول شماره ب). براى بررسى توانمندسازى اجتماعى ابتدا آز آزمون لون استفاده

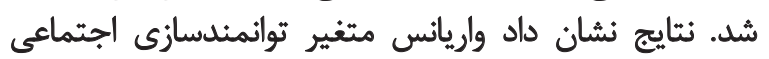

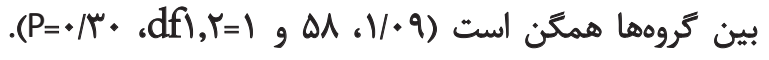

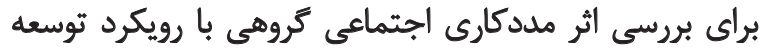

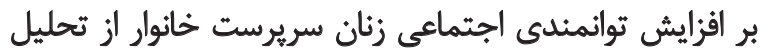
كوواريانس استفاده شد. بر اساس ائن زئن آزمون بين توست خانمندسار إنى تحلي 
جدول ع. تحليل كوواريانس توائمندسازى اجتماعى و مؤلفههاى آن در كروههاى آزمايش و كتترل زنان سريرست خاثوار

\begin{tabular}{|c|c|c|c|c|c|c|}
\hline مجذور اتا & سطح معنى هارى & مقدار F & ورجه آزادى & مياتكين مجذورات & مجموع مجذورات & منيع تغييرات \\
\hline$m$ & $<\cdot 1 \cdot \bullet 1$ & $r \Delta / r q$ & 1 & eve/m & ene/ry & يجيش آزمون توانمندسازيى الجتماعى \\
\hline \multirow[t]{3}{*}{+198} & $<+1++1$ & IIr/Ar & 1 & $r+r e / u$ & $r+r / q u$ & بين كروهـا \\
\hline & & & $\Delta v$ & relse & 101288 & درون كووهها \\
\hline & & & \&. & & $1 \pi \cdot m$ & كل \\
\hline.$/ M$ & $<+1+\infty$ & IV/OA & 1 & res/ar & res/ar & ييش أزمون ششاركت در امور اجتماعى \\
\hline \multirow[t]{3}{*}{. IE9 } & $<* \% 1$ & IIr/ET & 1 & $r m T / . \Delta$ & $T m / .0$ & بين كروهها \\
\hline & & & ar & $r \cdot / A V$ & WAVAY & درون كروهها \\
\hline & & & e. & & $\Delta 9 . .+f$ & 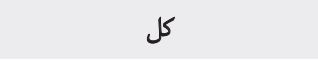 \\
\hline 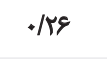 & $<* / *+1$ & $10 \mathrm{r} / \mathrm{VV}$ & 1 & $M T / F a$ & $m \pi / p q$ & ييش آزمون جمع كرايع \\
\hline \multirow[t]{3}{*}{$\cdot M r$} & $<* / . \cdot 1$ & rW & 1 & $\pi / r$. & $\pi / r$. & يين كروهها \\
\hline & & & $\Delta V$ & VAT & $A V / N F$ & درون Sروهها \\
\hline & & & 9. & & IFA19 & كل \\
\hline
\end{tabular}

توانبخننى

آموزشى كارآفرينى در مقايسه با زنانى كه در اين دوره شركت

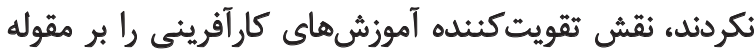

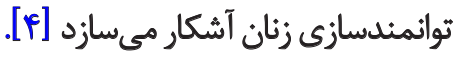

در بحث توانمندسازى زنان بهندرت به موانع روانى مبرداخته

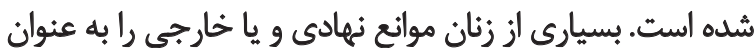

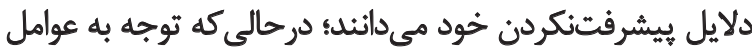

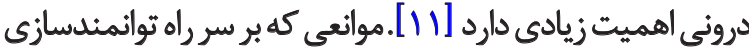

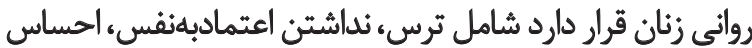

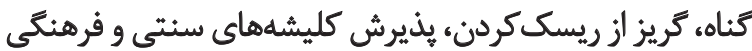

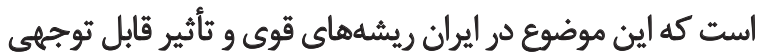

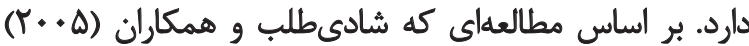

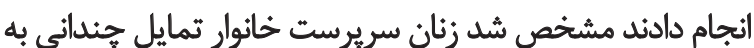

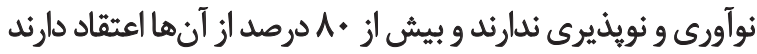

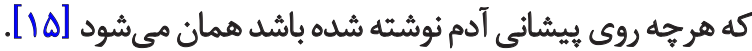

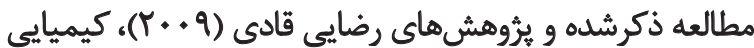

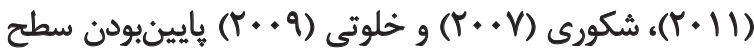

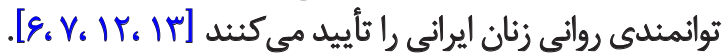

مسائل فرهنكي، محدوديتهاي زيادى بهائه شبكه روابط

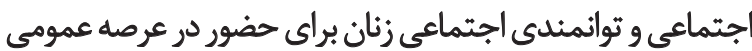

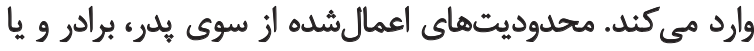

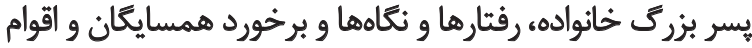

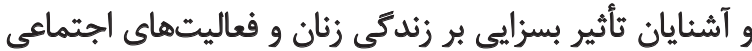

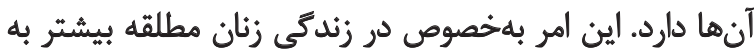

كنترل تفاوت معنادارى وجود دارد. بنابراين وجود تففاوت معنادار

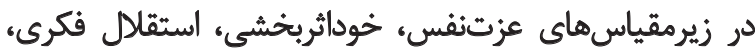

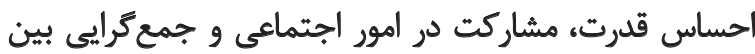

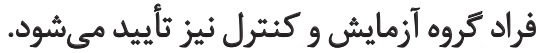
در رابطه با مطالعات همسو، نتايج يزوهش يحيى آبادى و

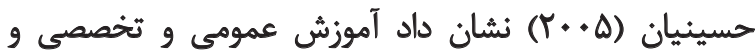

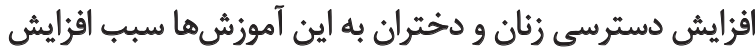

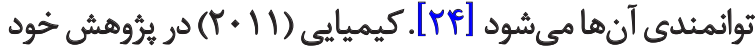

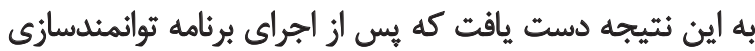

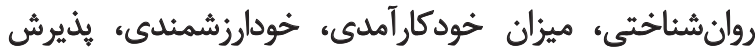

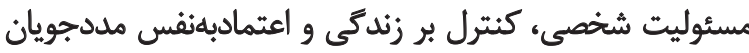

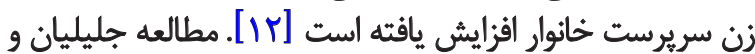

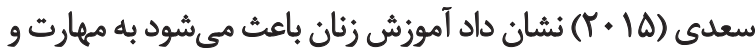

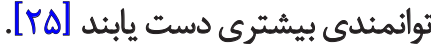

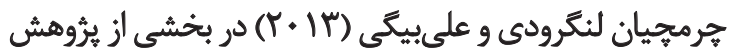

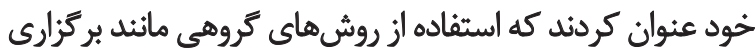

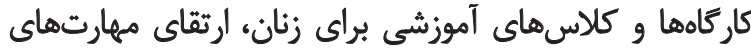

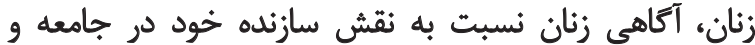

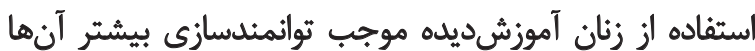

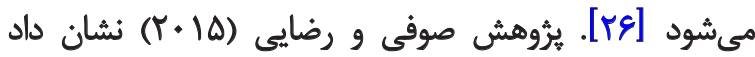

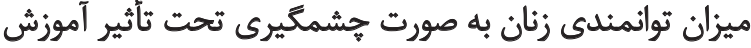

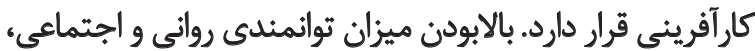

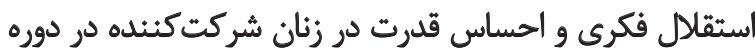




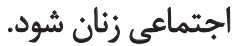

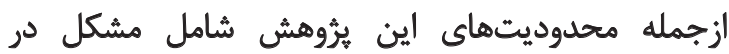

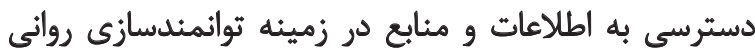

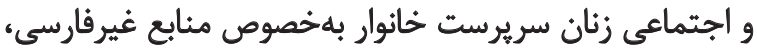

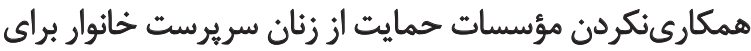

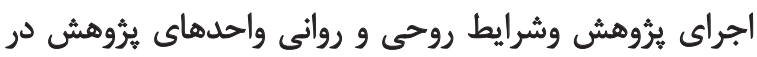

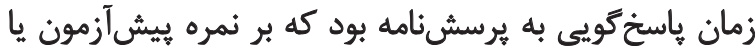
يس آزمون اثر كذاشته است.

ايده انجام اين تحقيق، مفهوم ديدكاه توسعه مددكارى

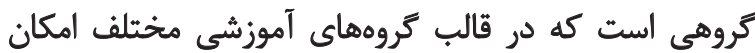

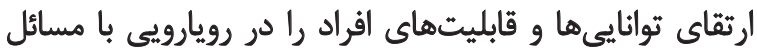

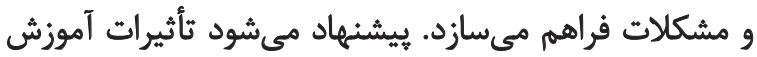

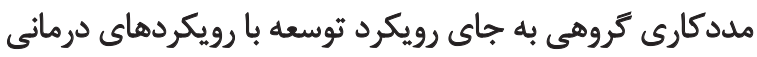

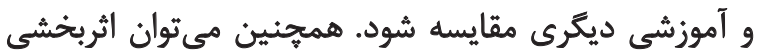

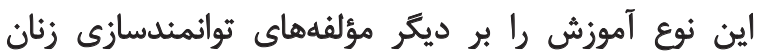

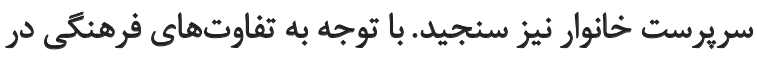

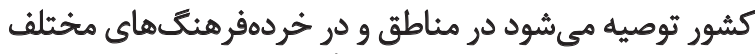

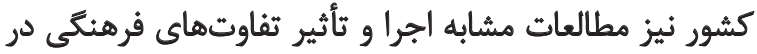

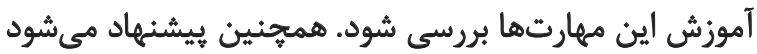

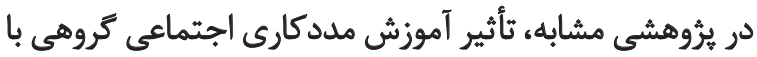

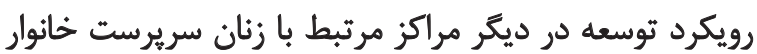

در سراسر كشور بررسى شود.

زيشنهاد مى شود براى ارتقاى توانمندسازى روانى و اجتماعى إنى

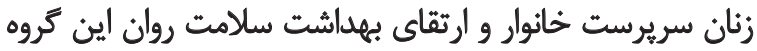

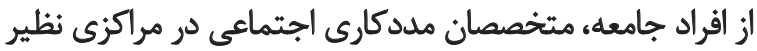

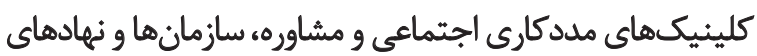

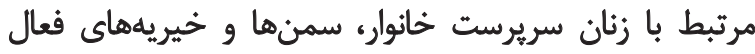

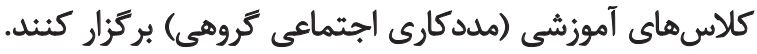

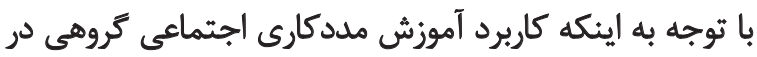

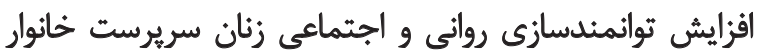

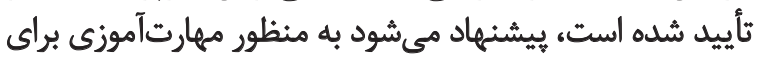

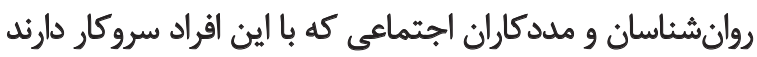

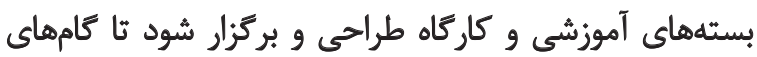

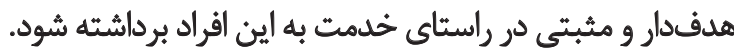

در اين زمينه ميتوان با تهيه و توزيع كثابجههاي آموزشي

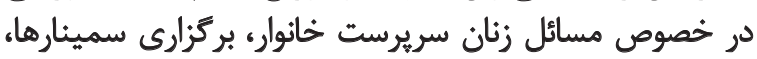

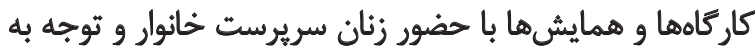

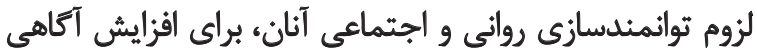

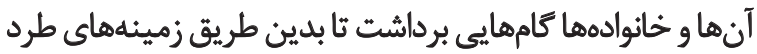

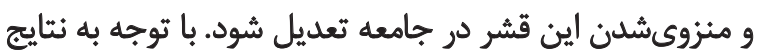

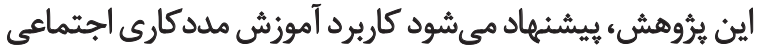

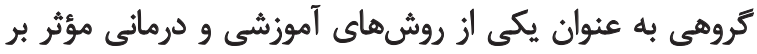

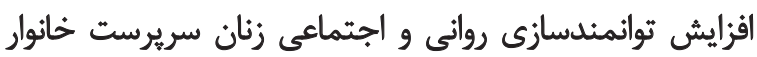

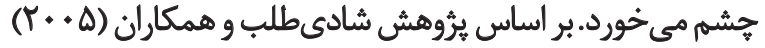

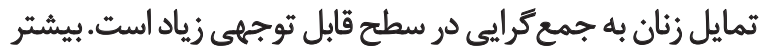

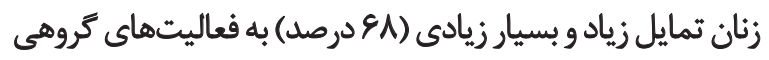

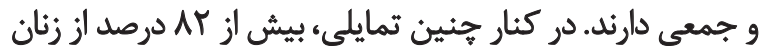

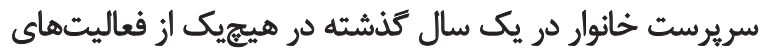

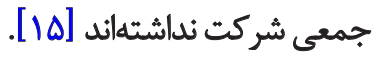

بر اساس جلسات مداخله بركزارشده، بيشتر زنان سريرست

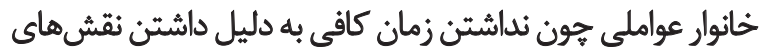

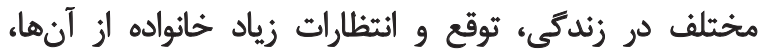

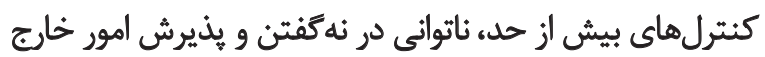

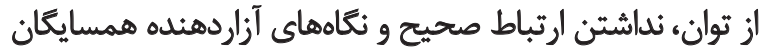

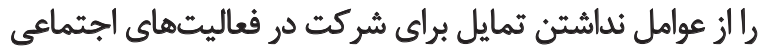

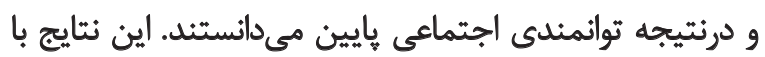

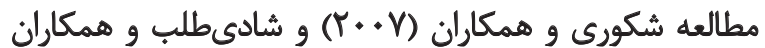

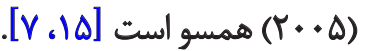

زنان سريرست خانوار فشارهاى واردشده از سوى بدر يا برادر

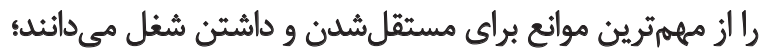

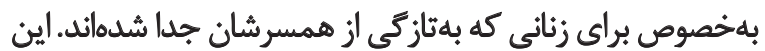

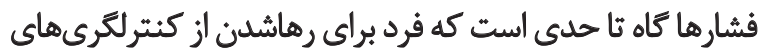

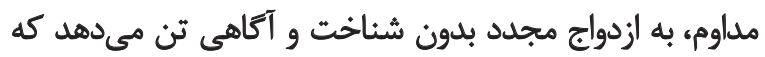

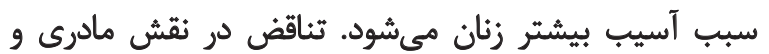

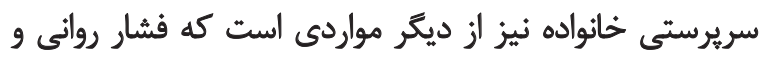

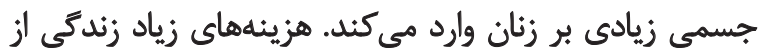

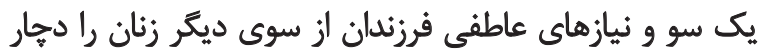

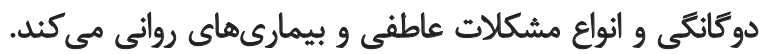

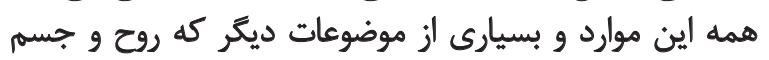
زنان سريرست خانوار رامىفرسايد موانع مسير توانمندسازى زنان

محسوب ميى رنون.

\section{نتيجلمَيرى}

با توجه به نتايج حاصل از اين تحقيق، تقويت احساس

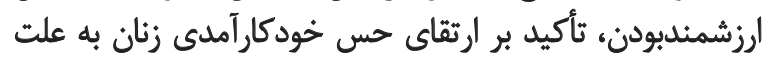

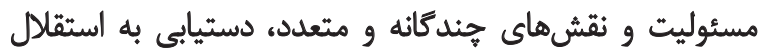

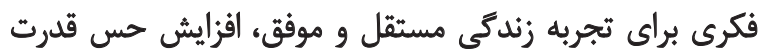

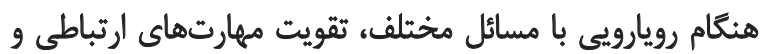

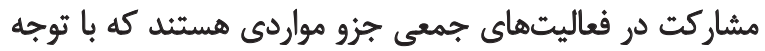

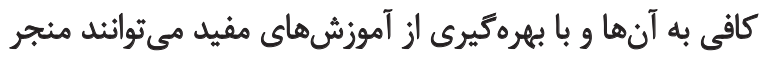

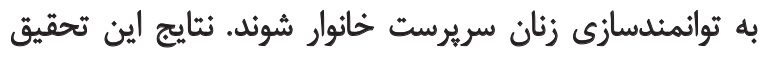

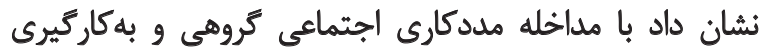

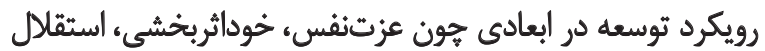

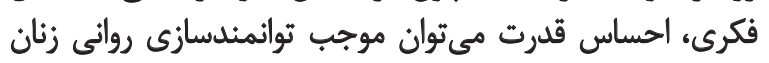

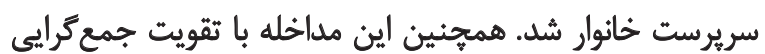

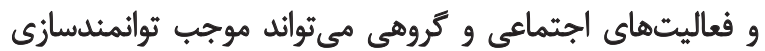


مورد توجه بيشتر كاركنان و برنامهريزان حوزه سلامت روان قرار

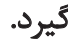

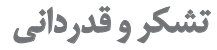

اين مقاله از ياياننامه كارشناسى ارشد خانم الهام ترابى مومن در

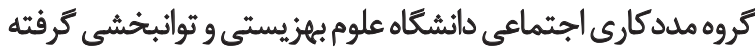

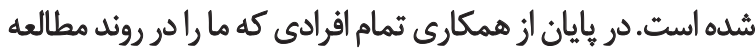

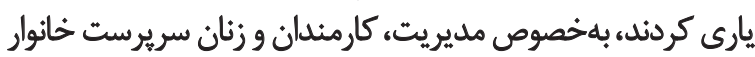
تحت يوشش مؤسسه امام على (ع) سياسكَّز إرى ميى كنيم. 


\section{References}

[1] Telozad M. [Prevalence of depression in women headed households (Persian)]. Payam-e Zan. 2007; 16(184-185):280.

[2] Bakhtiyari A, Mohebbi F. [Government and head householder women (Persian)]. Journal of Womens Strategic Studies. 2006; $9(34): 67$.

[3] Department of Reducing Social Disorder. [The role of technical and vocational skill training in empowering women-headed households as a social disorder (Persian)]. Tehran: Iran Technical \& Vocational Training Organization; 2011.

[4] Sufi M, Rezaei AA. [Study the effect of entrepreneurship, as a cultural factor, on the empowerment of women (Persian)]. Journal of Cultural Management. 2015; 9(27):15-28.

[5] Mohammad Moradi B. [Effects of union programs carpet city peers on empowerment of rural women: A case study of rural women carpet weavers, Safiabad, Biashush and Zlan (Persian)] [MSc. thesis]. Tehran: University of Tehran; 2010.

[6] Rezaei Ghadi Kh. [Indicators of empowerment of women heads of household. Proceedings of the conference and be synergistic capabilities of women heads of households (Persian)]. Paper presented at: The Second Conference on Empowering of HeadFamilies Women. 30 June 2016; Tehran, Iran.

[7] Shakoori A, Rafatjah M, Jafary M. [An analysis of factors affecting women's empowerment components (Persian)]. Women in Development \& Politics. 2007; 5(1):1-26.

[8] Shaditalab J. [Practices empower women heads of households (Persian)]. Tehran: Center for Women's Studies of Tehran University; 2004.

[9] Bandura A. Perceived self-efficacy in cognitive development and functioning. Educational Psychologist. 1993; 28(2):117-48. doi: 10.1207/s15326985ep2802_3

[10] Abbasi-Shavazi MJ, Alimandegarie M. [The effects of various dimensions of women's autonomy on fertility behavior in Iran (Persian)]. Women in Development \& Politics. 2010; 8(1):31-51.

[11] Sandberg S. Women, work, and the will to lead. New York: Penguin Random House; 2013.

[12] Kimiaee SA. [Methods used for empowering head-of-household women (Persian)]. Journal of Social Welfare. 2011; 11(40):63-92.

[13] Khalvati M. [House wives women's empowerment and its effective factors on dynamic process in Shiraz, 2007 (Persian)]. Social Research. 2009; 2(4):153-71.

[14] Grayinezhad AZ, Shaditalab Zh. [Poverty of women headed households (Persian)]. Journal of Women in Development \& Politics. 2004; 2(1):49-70.

[15] Shaditalab Zh, Vahabbi M, Varmazyar H. [Income poverty, only one aspect of female headed houshold's poverty (Persian)]. Journal of Social Welfare. 2005; 4(17): 227.

[16] Addelyan Rasi H. Empowering women in the Middle East by psychosocial interventions: Can provision of learning spaces in individual and group sessions and teaching of coping strategies improve women's quality of life [ $\mathrm{PhD}$ dissertation]. Linköping: Linköping University; 2013.
[17] Eqlima M. [Working with groups, recognition, treatment and dynamics (Persian)]. Tehran: Espand-e Honar; 2003.

[18] Cherayi S, Jose JP. Empowerment and social inclusion of muslim women: Towards a new conceptual model. Journal of Rural Studies. 2016; 45:243-51. doi: 10.1016/j.jrurstud.2016.04.003

[19] Francis East J, Roll SJ. Women, poverty, and trauma: An empowerment practice approach. Social Work. 2015; 60(4):279-86. doi: $10.1093 / \mathrm{sw} / \mathrm{swv} 030$

[20] Hunter BA, Jason LA, Keys CB. Factors of empowerment for women in recovery from substance use. American Journal of Community Psychology. 2012; 51(1-2):91-102. doi: 10.1007/ s10464-012-9499-5

[21] Mason KO, Smith HL. Women's empowerment and social context: Results from five Asian countries. Washington, D.C.: Gender and Development Group, World Bank; 2003.

[22] Mahdiyanfar F, Kimiaei SA, Ghanbari Hashemabadi BA. [Examining the effectiveness of psycho-social empowerment based on choice theory on reducing depression and aggression in women with husbands in prison in 2014 (Persian)]. Journal of Forensic Medicine. 2016; 21(3):167.

[23] Delavar A. [Theoretical and practical research in the humanities and social sciences (Persian)]. Tehran: Roshd; 2007.

[24] Hosseinian S, Tabatabaei Yahyaabadi Sh. [Empowerment of women heads of families through group counseling, awareness and entrepreneurship (Persian)]. Journal of Family Research. 2005; 1(4):361-68.

[25] Jalillans S, Sadi H. [Investigation effect of socio-economical components on rural women's psychological empowerment in Islamabad-e Qarb (Persian)]. Journal of Rural Research. 2015; 6(4):745-67.

[26] Charmchian Langerodi M, Alibaygi AH. [An investigation of effective factors on rural women's psychological empowerment in Sari (Persian)]. Journal of Women and Society. 2013; 4(13);16592. 